DOI https://doi.org/10.18551/rjoas.2017-06.38

\title{
PRICE EFFICIENCY OF SHALLOT MARKETING IN RURAL AREA OF INDONESIA
}

\author{
Hardana Andrean Eka*, Pariasa Imaniar Ilmi, Pratiwi Destyana Ellingga \\ Faculty of Agriculture, University of Brawijaya, Malang, Indonesia \\ *E-mail: andrean@ub.ac.id
}

\begin{abstract}
System for the marketing onion still controlled by intermediary traders with offers a price relatively higher. The price of onions red high in the market not always the advantage of farmers, the condition of being actually happened was the greatest advantage obtained the traders more perform the function of marketing. The purpose of this research is to analyze about pricing efficiency in transportation and processed that is for marketing commodities onion. The measurement of efficiency price can be reviewed according to function transportation costs and the cost of function processing they had spent to marketing onion. Pricing efficiency by function transportation that is the difference between the price between place marketing onion in the study areas and not larger than transportation costs issued by institutions marketing. Based on pricing efficiency, marketing onion at the research to all the marketing can said to have been efficient, it was because the proportion of profit marketing or is higher than the cost of marketing issued.
\end{abstract}

\section{KEY WORDS}

Price efficiency, transportation, function, cost.

Institutions of Shallot marketing is an organization that having role to play in channel produce Shallot to the consumer an end by performs the functions of marketing (Barakade A.J. et al, 2011 and Salazar, 2015.). An each marketing channel has different benefits different again to of the each institution marketing involved in these activities. The shorter marketing outlets will give greater advantage to producers compared with marketing outlets long (Rediansyah, 2003).

Marketing Shallot still involves several institutions marketing, as traders, the large areas, the large outside the region, and sellers. It was because farmers indirect selling commodities of Shallot directly to the consumer. This condition has the problem in Shallot marketing are still dominated technique sales is traditional and the prices must be the show standard the quality of the outcome crops. The impact of occurring namely the divisions of the price or farmers it can be said not in proportion to the cost of marketing have been issued (Marsha, 2011; Obasi I.O., Emenam O., 2014).

Now the system marketing of Shallot still controlled by intermediary traders with offers a price relatively higher, in addition transactions are in cash by intermediary traders after their crops onion weighed (Rediansyah, 2003). The ties cooperation and ease is obtained. Money cause farmers choose sell their harvest onion as the price specified directly by intermediary traders. The price of onions red high in the market not always the advantage of farmers, the condition of being actually happened was the greatest advantage obtained the traders more perform the function of marketing (Marsha, 2011).

Based on the description above, and then required analysis research on the efficiency of the price of a commodity Shallot. Marketing onion conducted by marketing institutions will determine much of the marketing based on the efficiency of the function of marketing conducted by marketing of each organization. Hence the purpose of this research is to analyze about the efficiency of a price on transportation and processing which is found in marketing commodities Shallot. 


\section{METHODS OF RESEARCH}

The determination of recipient the research was done in purposive namely in Malang areas consist of Batu city, Malang city and Malang regency. The determination of respondents for marketing determined approach in non probability of sampling with the methods snow ball sampling that is following a groove marketing starting from farmers onion down to the level consumers the end. Based on the level a manufacturer or farmers will know where the flow of products and institutions what was involved in product marketing until to the consumer the end. Virtue of a groove marketing in the regions research, obtained various institutions marketing involved was two amount of intermediary traders, three amount of large trades on regional level, three amount of large traders on outside the region level, and five amount of retailer traders, so the total traders respondents there were 13 people.

The method of analysis the data used in accordance with research objectives that is efficiency marketing. To analyze marketing onion required pricing efficiency to transport and processed. The measurement of efficiency price can be reviewed according to cost of function transportation and the cost of function processing had spent to marketing onion. Pricing efficiency by function transportation that is the difference between the price between place marketing Shallot in the study areas and not larger than transportation costs issued by institutions marketing. Based on the previous research by Zalukhu (2009); Layade A.A., and Adeoye I.B (2014), for analysis pricing efficiency according to transportation costs can formulated as follows:

$$
P A-P B \geq B T
$$

Where: $\mathrm{PA}=$ Selling price in final place, $\mathrm{PB}=$ Selling price in starting place, $\mathrm{BT}=$ Transportation cost.

Price efficiency based on processing function is the price difference between Shallot and marketing agencies do not outweigh the cost function processing issued by marketers. Processing function consists of sorting and grading costs, packaging, loading and unloading. The calculation for the analysis of the efficiency of the price according to the cost of processing is as follows:

$$
P A-P B \geq B P
$$

Where: $\mathrm{PA}=$ Selling price in final place, $\mathrm{PB}=$ Selling price in starting place, $\mathrm{BP}=$ Processing cost.

\section{RESULTS AND DISCUSSION}

Shallot marketing channel of a series of institutions marketing traversed products commodities Shallot to the direction of the distribution of the product of producers to consumers. The shorter marketing outlets will give greater advantage to producers compared with marketing outlets long. The current marketing Shallot at various degrees of in the study areas it appears that there are several institutions marketing involved in an activity marketing starting from farmers, intermediary traders, large traders, and retailer trader, until with final consumers. Based on the research done there are four marketing channel in the research areas namely.

A sale is a weight that is based on weight a unit of pounds in the form of a sack of Shallot, tied up. In general Shallot sold by farmers' respondents at the condition of being is dried up for 4-6 day. Sales onion done farmers that is waiting for buyers coming to the dried up place in land and also of farmers' house.

Interdiatery traders are the marketing institutions of buy onion directly from the farmers. The process of purchasing is farmers who visited directly intermediary traders and traders who visited directly the farmer. In general intermediary traders are from local village and neighbors' village. The process of selling the purchases through transactions bargain price 
between them, with reference to commodity prices onions a prevailing red at the time. Marketing institutions act as middle-men in research locations as many as two people.

1.
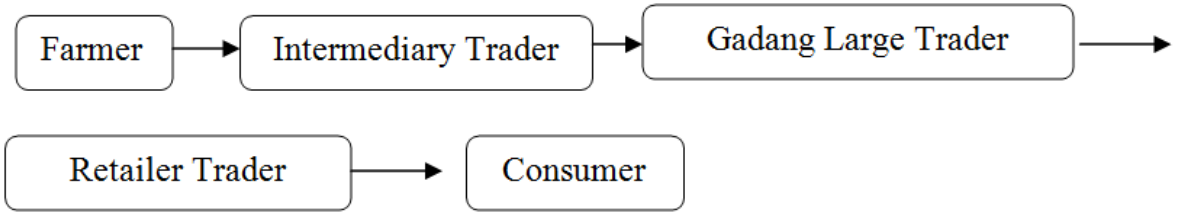

2.

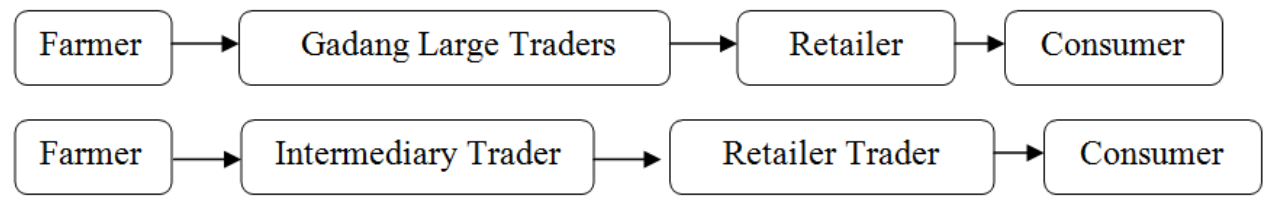

4.

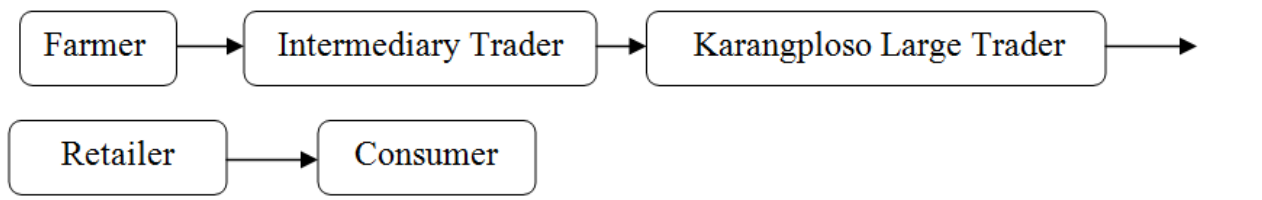

Marketing Channel I

a. Intermediary Trader

IDR 8.500 - IDR $7.000 \times(1 / 1-1,02)>$ IDR 30

IDR $8.500-$ IDR $7.140>$ IDR 30

IDR $1.360>$ IDR 30

b. Karang Ploso Large Trader

IDR 10.500 - IDR $8.500 \times(1 / 1-1,03)>$ IDR 11,7

IDR $10.500-$ IDR $8.755>$ IDR 11,7

IDR $1.745>$ IDR 11,7

c. Reatailer Trader

IDR 12.500 - IDR $10.500 \times(1 / 1-1,02)>$ IDR 51

IDR $12.500-$ IDR $10.710>$ IDR 51

IDR $1.790>$ IDR 51

\section{Marketing Channel II}

a. Batu Large Trader

IDR 9.000 - IDR $7.000 \times(1 / 1-1,02)>\operatorname{Rp~} 8,5$

IDR $9.000-$ IDR $7140>\operatorname{Rp} 8,5$

IDR $1.860>$ IDR 8,5

b. Retailer Trader

IDR 11.500 - IDR $9.000 \times(1 / 1-1,01)>$ IDR 66,7

IDR 11.500 - IDR $9.090>$ IDR 66,7

IDR $2.410>$ IDR 66,7
Marketing Channel III

a. Intermediary Trader

IDR 8.500 - IDR $7.000 \times(1 / 1-1,01)>$ IDR 24

IDR 8.500 - IDR $7.070>$ IDR 24

IDR $1.430>$ IDR 24

b. Gadang Large Trader

IDR 10.500 - IDR $8.500 \times(1 / 1-1,03)>$ IDR 16,7 IDR 10.500 - IDR 8.755 > IDR 16,7

IDR $1.745>$ IDR 16,7

C. Retailer Trader

IDR 13.000 - IDR $10.500 \times(1 / 1-1,02)>$ IDR 114

IDR 12.500 - IDR $10.710>$ IDR 114

IDR $2.290>$ IDR 114

\section{Marketing Channel IV}

a. Intermediatery Trader

IDR 8.500 - IDR $7.000 \times(1 / 1-1,02)>$ IDR 26,7

IDR 8.500 - IDR 7.140> IDR 26,7

IDR $1.360>$ IDR 26,7

b. Retailer Trader

IDR 11.000 - IDR $8.500 \times(1 / 1-1,02)>$ IDR 82,5 IDR $11.000-$ IDR $8.670>$ IDR 82,5

IDR $2.330>$ IDR 82,5

The large traders from the regions and outside the region are traders who buy Shallot of various intermediary traders and buy directly to local farmers, with the number of the purchase of the major party. Generally, large trader had big patron intermediary traders who sell onion. Traders large buy onion of intermediary traders are already in the form of without fastenings in a sack and others in the form of connective in a sack. While of derived from farmers in overall still in connective in a sack. Marketing institutions act as the large areas as many as three people and the outside region of large traders in the research locations as many as three people.

Retailer traders are traders who come straight with consumers. Retailer traders not doing process of packing repeated because directly sell Shallot that has been purchased in the form of without fastenings. 
Analysis of price efficiency this price measuring the cost of transportation and the cost of processing to each marketing institution involved. The measurement of efficiency based on a calculation the difference between the prices actual a commodity at a cost of the cost of function marketing done by institutions marketing involved.

Table 1 - Price efficiency based on transportation function in Shallot institutional marketing

\begin{tabular}{cccc}
\hline Marketing Channel & Marketing Institution & Price Gap (IDR/Kg) & Transportation Cost Average \\
\hline I & Intermediary Trader & 1360 & 30 \\
& Large Trader Karang Ploso & 1745 & 11,7 \\
II & Retailer Trader & 1790 & 51 \\
& Batu Large Trader & 1860 & 8,5 \\
III & Retailer Trader & 2410 & 66,7 \\
& Intermediary Trader & 1430 & 24 \\
Large Trader Gadang & 1745 & 16,7 \\
IV & Retailer Trader & 2290 & 114 \\
& Intermediary Trader & 1360 & 26,67 \\
& Retailer Trader & 2330 & 82,45 \\
\hline
\end{tabular}

\section{Marketing Channel I}

a. Intermediary Trader

IDR $8.500-$ IDR $7.000 \times(1 / 1-1,02)>$ IDR 55 IDR $8.500-$ IDR $7.140>$ IDR 55

IDR $1.360>$ IDR 55

b. Karang Ploso Large Trader

IDR 10.500 - IDR $8.500 \times(1 / 1-1,03)>$ IDR 76,7

IDR 10.500 - IDR $8.755>$ IDR 76,7

IDR 1.745 > IDR 76,7

c. Retailer Trader

IDR 12.500 - IDR $10.500 \times(1 / 1-1,02)>$ IDR 70

IDR 12.500 - IDR $10.710>$ IDR 70

IDR $1.790>$ IDR 70

Marketing Channel II

a. Batu Large Trader

IDR 9.000 - IDR $7.000 \times(1 / 1-1,02)>$ IDR 100,8

IDR 9.000 - IDR $7140>$ IDR 100,8

IDR $1.860>$ IDR 100,8

b. Retailer Trader

IDR 11.500 - IDR $9.000 \times(1 / 1-1,01)>$ IDR 70

IDR 11.500 - IDR $9.090>$ IDR 70

IDR $2.410>$ IDR 70

\section{Marketing Channel III}

a. Intermediary Trader

IDR 8.500 - IDR $7.000 \times(1 / 1-1,01)>$ IDR 55

IDR $8.500-$ IDR $7.070>$ IDR 55

IDR $1.430>$ IDR 55

b. Gadang Large Trader

IDR 10.500 - IDR $8.500 \times(1 / 1-1,03)>$ IDR 97,9 IDR 10.500 - IDR $8.755>$ IDR 97,9

IDR $1.745>$ IDR 97,9

C. Large Trader

IDR 13.000 - IDR $10.500 \times(1 / 1-1,02)>$ IDR 154

IDR 12.500 - IDR $10.710>$ IDR 154

IDR $2.290>$ IDR 154

\section{Marketing Channel IV}

a. Intermediary Trader

IDR 8.500 - IDR $7.000 \times(1 / 1-1,02)>$ IDR 335

IDR $8.500-$ IDR 7.140> IDR 335

IDR $1.360>$ IDR 335

b. Retailer Trader

IDR 11.000 - IDR $8.500 \times(1 / 1-1,02)>$ IDR 70

IDR $11.000-$ IDR $8.670>$ IDR 70

IDR $2.330>$ IDR 70

Based on the calculation of in table 1, can be seen that on average transportation costs done by each marketing institutions involved in every marketing outlets. A marketing outlets it can be said efficient when value the difference between the price greater than values on average the money that has been issued for marketing onion. On the other hand, a marketing outlets said inefficient when value the difference between the price smaller than values on average cost.In the analysis price efficiency according to function transportation, all the marketing has reached price efficiency.

Approach pricing efficiency also obtained from function processing consisting of sorting and grading, packaging, loading and unloading. Activities sorting to separate onion the best of spoiled or is misshapen. While grading is pengkelasan criteria onion according to the shape and size of the amount tubers onion. After conducted sorting and grading, onion packed with using the sacks plait plastic perforated holes. Loading and unloading activities onion who has packed in a sack plait plastic and kemudan carried into pick up. 
Table 2 - Price Efficiency Based on Processing Function in Market institutional Shallot

\begin{tabular}{cccc}
\hline Marketing Channel & Marketing Institutional & Price Gap (IDR/kg) & Transportation Cost Average \\
\hline & Intermediary Trader & 1360 & 55 \\
& Karang Ploso Large Trader & 1745 & 76,7 \\
II & Retailer Trader & 1790 & 70 \\
& Batu Large Trader & 1860 & 100,8 \\
III & Retailer Trader & 2410 & 70 \\
& Intermediary Trader & 1430 & 55 \\
IV & Pedagang Large Trader & 1745 & 97,9 \\
& Retailer Trader & 2290 & 154 \\
& Intermediary Trader & 1360 & 355 \\
\end{tabular}

Based on the results in table 2, according to function processing consisting of sorting and grading, packaging, loading and unloading and, can said to have efficient. It is applicable to marketing outlets it can be said efficient when value the difference between the price greater than values on average cost. On the other hand, marketing outlets said inefficient when value the difference between the prices smaller than values on average cost. Hence the efficiency of marketing outlets was found in all value the difference between the prices of all marketing outlets greater than values on average cost processing.

\section{CONCLUSION}

Based on price efficiency, marketing of Shallot at the research to all the marketing can said to have been efficient, it was because the proportion of profit marketing or is higher than the cost of marketing issued. In the next research, can research supply chain management (SCM) analysis of marketing relationship between suppliers seeds, farmers, traders, the large regions and outside the region, and a retailer. Because it can develop this business and compete superior in marketing onion.

\section{REFERENCES}

1. Asmara, Rosihan and Ardhiani, Ruri. (2010). The Market Integration Analysis In Shallot Marketing System. AGRISE Volume X No. 3.

2. Barakade A.J., Lokhande T.N.and Todkari G.U. (2011). Economics of onion cultivation and its marketing pattern in satara district of Maharashtra. International Journal of Agriculture Sciences. Vol. 3, Issue 3, 2011, PP-110-117.

3. Easwarana, Salvadi R and Ramasundaramb, P. (2008). Whether Commodity Futures Market in Agriculture is Efficient in Price Discovery? - An Econometric Analysis. Tamil Nadu Agricultural University, Anbil Dharmalingam Agricultural College and Research Institute, Tiruchirappalli.

4. Firdaus, Muhammad and Gunawan, Irwanto. (2012). Integration Among Regional Vegetable Markets In Indonesia. J. ISSAAS Vol. 18, No. 2:96-106.

5. Grema, I. J., Gashua, A.G. Makinta A.A. (2015). Marketing Analysis of onion in Bade and Geidam Local Government Areas of Yobe State, Nigeria. IOSR Journal of Applied Physics (IOSR-JAP)...Volume 7, Issue 1 Ver. I (Jan.-Feb. 2015), PP 73-78.

6. Hailu, Getu., Goddard, Ellen W., and Jeffrey, Scott R. (2005). Measuring Efficiency in Fruit and Vegetable Marketing Co-operatives with Heterogeneous Technologies in Canada. Agricultural Marketing and Business, Department of Rural Economy, University of Alberta. Canada.

7. Jema Haji. (2008). Economic Efficiency and Marketing performance of Vegetable Production in the Eastern and Central Parts of Ethiopia. Doctoral Thesis Swedish University of Agricultural Sciences. 
8. Obasi I.O and Emenam, O. (2014). Marketing Performance of Onions in Ikwuano and Umuahia Local Government Area, Abia State, Nigeria. European Journal of Business and Management. Vol.6, No.7

9. Layade A.A., and Adeoye I.B. (2014). Analysis of Price and Market Integration for Onion in Rural-Urban Markets of Oyo State, Nigeria. International Journal of Economics, Finance and Management. Vol.3, No.5.

10. Marsha, Dhevi Aprilia. (2011). Analysis of Shallot (Allium ascalonicum L.) Commodity Agribusiness in Sukomoro Subdistrict Nganjuk Regency. Agriculture Faculty. University ofBrawijaya. Malang. Indonesia.

11. Rajendran, Srinivasulu. (2015). Price Transmission Process in Vertical Markets: an Empirical Analysis of Onion Markets in Tamil Nadu State (India). European Journal of Sustainable Development (2015), 4, 1, 9-22.

12. Rediansyah. (2003). Analysis of Leaf Onion Marketing System (Case in Cijarian Pandai Village Kadudampit Subdistrict Sukabumi Regency). Thesis. Department of Agriculture Socio-Economic Science. Agriculture Faculty. IPB. Bogor. Indonesia.

13. Rosyadi, Imron and Purnomo, Didit. (2014). Profitability and Efficiency of Red Onion Farming. Jurnal Ekonomi Pembangunan, 15 (2), December 2014, 117-127.

14. Rukmana, R. (1995). Onion the cultivation and processing after harvest. Kanisius. Jakarta. Indonesia.

15. Salazar, Rodrigo Andres Valdes. (2015). Market Intregation and Pricing Efficiency, Empirical Analysis to the Agribusiness Sector. Agricultural Economics at The Faculties of Agricultural Sciences. Georg-August University Gottingen. Germany.

16. Sujarwo and Sayed, Saghaian. (2013). Profit Gap Analysis on the Small Scale Production of Shallot: A Case Study in a Small Village in East Java Province of Indonesia. Southern Agricultural Economics Association SAEA Annual Meeting. Orlando, Florida.

17. Susanawati,Jamhari, Masyhuri, Dwidjono, H. D. (2015). Price Behavior and Market Integration of Shallot in Java Indonesia. Volume 3 Issue.

18. Zalukhu, Yuniasti. (2009). Analysis of Farming and marketing of national Hybrid variety of paddy (case of Bondoyudo Variety in Gapoktan Tani Bersatu, Cibungbulang Subdistrict, Bogor Regency). Department of Agriculture Science. Agriculture Faculty. Bogor Agriculture Institute. Indonesia.

19. Wahyudin, Moh; Maksum, Moch; and Yuliando,Henry. (2015). The Shallot Pricing in the View of Import Restriction and Price Reference. Agriculture and Agricultural Science Procedia 3 (2015) 132 - 136.

20. Waryanto, Budi; Chozin, MA; Dadang, Putri, Eka Intan K. (2014). Environmental Efficiency Analysis of Shallot Farming: A Stochastic Frontier Translog Regression Approach. Journal of Biology, Agriculture and Healthcare. Vol.4, No.19. 